\title{
Enhanced heterotrophic activity in the surface microlayer of the Mediterranean Sea
}

\author{
Ingrid Obernosterer ${ }^{1, *}$, Philippe Catala ${ }^{1}$, Thomas Reinthaler $^{2}$, Gerhard J. Herndl ${ }^{2}$, \\ Philippe Lebaron ${ }^{1}$
}

${ }^{1}$ Observatoire Océanologique de Banyuls, Laboratoire d'Océanographie Biologique, Université Pierre et Marie Curie, CNRS UMR 7621, BP 44, 66651 Banyuls-sur-Mer Cedex, France

${ }^{2}$ Dept. of Biological Oceanography, Royal Netherlands Institute for Sea Research (NIOZ), 1790 AB Den Burg, The Netherlands

\begin{abstract}
The abundance and activity of heterotrophic and autotrophic organisms were determined in the surface microlayer (SML) at marine and estuarine sites in the NW Mediterranean Sea from May to July 2003. At all study sites, community respiration in the SML exceeded that in the subsurface water (SSW) by factors between 1.7 and 28. The abundance of heterotrophic bacteria and the major groups of the autotrophic community displayed consistent, but low enrichment factors (EF) for the SML (mean 1.3). In contrast, EF for the abundance of heterotrophic nanoflagellates and the concentration of particulate organic carbon were, on average, 4 and 7 , respectively. Community respiration rates in the SML were related to the concentration of total organic carbon; however, no relationship was detectable between community respiration and the abundance of the major groups of the heterotrophic and autotrophic community. Net community production, determined at 2 oligotrophic marine sites, displayed negative values for the SML, while in the SSW autotrophic processes balanced or exceeded heterotrophic processes. Similar rates of photochemical oxygen consumption were determined for the SML and the SSW. These results let us conclude that in situ primary production in the SML is not sufficient to support biological and photochemical mineralization at the air-water interface. We suggest that vertical transport of organic matter, mainly in colloidal and particulate form, to the air-water interface is the basis of the food web, thereby supporting net heterotrophy of the SML.
\end{abstract}

KEY WORDS: Surface microlayer $\cdot$ Community respiration $\cdot$ Net community production $\cdot$ Neuston

\section{INTRODUCTION}

Surface microlayers (SML) are a common phenomenon in most freshwater and marine environments. They represent the boundary layer between the atmosphere and aquatic systems and therefore, play a pivotal role in the transfer of gaseous, liquid and particulate matter across the air-water interface. The SML has traditionally been defined as the uppermost 1 to $1000 \mu \mathrm{m}$ of aquatic environments, but more recent conceptual models extend the surface layer to the upper $1 \mathrm{~m}$ divided into several sublayers $(10 \mathrm{~nm}$ to $1 \mathrm{~m}$; Hardy 1997). Distinct physical and chemical properties characterize the SML (Hunter 1997, Liss et al. 1997). The formation of the SML results from organic matter concentrated at the air-sea interface by a number of physical and biological processes, such as diffusion, turbulent mixing, transport by rising bubbles or buoyant particles and in situ primary production. Biological and photochemical mineralization and vertical transport are considered the major mechanisms responsible for the loss of SML material (Liss et al. 1997). Organisms present in the SML (so-called neuston) are, therefore, intermediary sources or sinks for inorganic and organic components and their activities could significantly impact the exchange of matter across the air-water interface.

To date, biogeochemical characterization of the SML has primarily focused on the concentration of inorganic and organic matter and the abundance of neustonic 
organisms, and it has become evident that the uppermost surface layer of a variety of freshwater and marine environments is enriched in organic matter and inorganic nutrients (see review by Lion \& Leckie 1981). It is also well-documented that several members of the hetero- and autotrophic community are more abundant in the SML than in the subsurface water (SSW) (see review by Hardy 1997). Enrichment factors (EF) for any of these chemical and biological parameters, however, vary widely among studies. The large variability in EF could reflect site-specific differences, but is also related to differences in depth layers sampled by the various types of sampling devices ( $30 \mathrm{~nm}$ to $1 \mathrm{~mm}$; Lion \& Leckie 1981) and to differences in the reference depths chosen (Agogué et al. 2004).

Comparatively few studies exist on neuston metabolic activity and their results are largely contradictory. Heterotrophic bacterial activity (measured via radiotracer incorporation) is reported to be enriched (Sieburth et al. 1976, Carlucci et al. 1986), depleted (Dietz et al. 1976, Bell \& Albright 1982, Bailey et al. 1983, Williams et al. 1986) or not substantially different (Hermannson \& Dahlback 1983, Garabétian 1990, Agogue et al. 2004) in the SML compared to the SSW. Higher microplankton respiration rates were measured in the SML than in the SSW in the Bay of Marseille (Mimura et al. 1988). Harvey \& Young (1980) reported a substantially higher contribution of respiring bacteria (determined by INT-formazan) in the SML of salt marshes than in the SSW, with most bacteria being attached to particles. Similarly, enhanced peptidehydrolysis rates were determined for dissolved organic matter originating from the SML compared to bulk waters (Kuznetsova \& Lee 2001). The enrichment in organic matter in the SML likely favors heterotrophic activity. Physical properties, however, such as shortterm variability in temperature and salinity as well as exposure to high intensities of solar radiation might retard overall metabolic activity in the SML. Similarly, measurements of phytoneuston activity (based on ${ }^{14} \mathrm{C}$ incorporation) indicate higher (Hardy \& Apts 1989), lower (Albright 1980, Hardy \& Apts 1984, Williams et al. 1986) or similar (De Souza Lima \& ChretiennotDinet 1984) rates of primary production in the SML compared to the SSW. The balance between growth-promoting and growth-inhibiting processes likely varies among systems and determines whether the SML represents a habitat of enhanced metabolic activity.

Generally, auto- and heterotrophic activity can be considered as sources and sinks of organic matter, respectively, and the balance between these processes determines the subsystem's overall metabolism. Previous studies on the SML were based on either of these 2 processes, while to the best of our knowledge, no attempt has been made thus far to compare the production and mineralization of organic matter in the SML of the marine environment.

In the present study, we determined chemical and biological characteristics of the SML along a transect from freshwater to offshore marine sites. We further investigated hetero- and autotrophic activity and the importance of photochemical processes in the SML and the SSW in 2 oligotrophic marine environments. Our results clearly show that in situ primary production in the SML is not sufficient to support the enhanced community respiration rates observed at the air-sea interface, resulting in the predominance of heterotrophic activity in the SML.

\section{MATERIALS AND METHODS}

Study sites. During May, June and July 2003, SML samples were collected at Stn SOLA (Station d'Observation Laboratoire Arago) in the bay of Banyuls-surMer (NW Mediterranean Sea; Table 1). Stn SOLA is a coastal, shallow $(26.5 \mathrm{~m})$, oligotrophic site, which had concentrations of $\sim 1 \mu \mathrm{g}$ chlorophyll a (chl a) $\mathrm{l}^{-1}$ in the water column during the sampling period (data on request from J. J. Naudin). Additional SML samples were collected in the River Rhône $\sim 1 \mathrm{~km}$ upstream from its estuary, in the estuary of the River Rhône and at the offshore Stn MOLA (Microbial Observatory Laboratoire Arago; Table 1). In the estuary of the River Rhône, a distinct lense influenced by freshwater extending to $\sim 7 \mathrm{~m}$ depth and characterized by a salinity of 35.9 was sampled. Stn MOLA is located above the Canyon Lacaze-Duthiers (1000 m) 18 nautical miles off Banyuls-sur-Mer.

Hourly mean wind speed measurements were obtained from Meteo France (French Weather Service) during the sampling period. The measurements were performed at Cap Bear, $3 \mathrm{~km}$ north of Stn SOLA.

Sampling. SML samples were collected from a zodiac with a metal screen according to the method of Garrett (1965). Our choice of the metal screen is based
Table 1. Sampling stations in NW Mediterranean Sea. SOLA: Station d'Observation Laboratoire Arago; MOLA: Microbial Observatory Laboratoire Arago

\begin{tabular}{|c|c|c|c|c|c|}
\hline Stn & $\begin{array}{l}\text { Lat. } \\
\left({ }^{\circ} \mathrm{N}\right)\end{array}$ & $\begin{array}{l}\text { Long. } \\
\left({ }^{\circ} \mathrm{E}\right)\end{array}$ & $\begin{array}{l}\text { Distance from } \\
\text { coast (n. miles) }\end{array}$ & $\begin{array}{l}\text { Depth } \\
\text { (m) }\end{array}$ & $\begin{array}{l}\text { Sampling } \\
\text { period }\end{array}$ \\
\hline River Rhône & $43^{\circ} 07^{\prime} 86^{\prime \prime}$ & $04^{\circ} 43^{\prime} 49^{\prime \prime}$ & 0.2 & 5 & Jul 2003 \\
\hline Rhône Estuary & $43^{\circ} 18^{\prime} 89^{\prime \prime}$ & $04^{\circ} 50^{\prime} 79^{\prime \prime}$ & 9.5 & 67 & Jul 2003 \\
\hline SOLA & $42^{\circ} 29^{\prime} 36^{\prime \prime}$ & $03^{\circ} 08^{\prime} 65^{\prime \prime}$ & 1 & 26.5 & May-Jul 2003 \\
\hline MOLA & $42^{\circ} 27^{\prime} 04^{\prime \prime}$ & $03^{\circ} 31^{\prime} 93^{\prime \prime}$ & 18 & 1000 & Jul 2003 \\
\hline
\end{tabular}


on a comparison of several sampling devices for the biological characterization of the SML (Agogué et al. 2004). The metal screen collects roughly the upper $250 \mu \mathrm{m}$ water layer (Garrett 1965). The mesh width of the metal screen was $1.25 \mathrm{~mm}$. The metal screen was immersed at an angle of $\sim 45^{\circ}$ in the water and subsequently raised through the surface water layer in a horizontal position. The metal screen was subsequently drained at an angle of $45^{\circ}$. To prevent inclusion of water adhering to the frame, the first $100 \mathrm{ml}$ of water draining from the metal screen were rejected. Prior to collection, the metal screen was rinsed several times with the respective sample water. The collection of $\sim 21$ of SML water required about $0.5 \mathrm{~h}$ with 1 metal screen. The SSW was sampled by submerging a closed Pyrex flask that was opened at $\sim 0.3 \mathrm{~m}$. Samples collected in the SML and the SSW were transferred to 91 polycarbonate (PC) carboys with a spigot at the bottom. Prior to sampling, the flask and the PC carboys were rinsed with $1 \mathrm{~N} \mathrm{HCl}$, Milli-Q water and 3 times with the respective water samples.

Irradiance measurements. Surface irradiance measurements were performed with an Eldonet broad band filter radiometer (Real Time Computer). The Eldonet measures ultraviolet (UV)-B radiation over the 280 to $315 \mathrm{~nm}$ wavelength range, UV-A radiation over the 315 to $400 \mathrm{~nm}$ wavelength range and photosynthetic active radiation (PAR, 400 to $700 \mathrm{~nm}$ ) (Häder et al. 1999). Integrated irradiance was calculated from measurements at 1 min intervals throughout the exposure period of experiments examining net primary production and photochemical oxygen demand (see next subsection). Integrated surface solar radiation varied between 6.2 and $9.9 \times 10^{3} \mathrm{~kJ} \mathrm{~m}^{-2}$ for PAR, between 1027 and $1583 \mathrm{~kJ} \mathrm{~m}^{-2}$ for UV-A and 22 and $35 \mathrm{~kJ} \mathrm{~m}^{-2}$ for UV-B (Table 2).

Community respiration and net primary production. Community respiration and net primary production were determined in dark and light bottle incubations, respectively, of unfiltered seawater from the SML and the SSW. Biological oxygen demand (BOD) bottles $(120 \mathrm{ml})$ were filled from the PC carboys using

Table 2. Intensities $\left(\mathrm{kJ} \mathrm{m}^{-2}\right)$ of photosynthetic active radiation (PAR), ultraviolet (UV)-A and UV-B radiation above the sea surface in June and July 2003. Values are integrated over the time period 10:00 to $18: 00 \mathrm{~h}$

\begin{tabular}{|lccc|}
\hline Date & PAR & UVA & UVB \\
\hline Jul 1 & 8321 & 1366 & 30 \\
Jul 5 & 9335 & 1535 & 35 \\
Jul 7 & 9898 & 1583 & 35 \\
Jul 9 & 6176 & 1027 & 22 \\
Jul 21 & 7834 & 1151 & 26 \\
\hline
\end{tabular}

silicone tubing fixed to the spigot of the PC carboys. Quartz-glass BOD bottles were used for net primary production measurements and community respiration was determined in borosilicate BOD bottles wrapped in aluminum foil. To expose SML and SSW to solar radiation, the quartz BOD bottles (height $10 \mathrm{~cm}$, diameter $5 \mathrm{~cm}$ ) were horizontally submerged in an outdoor incubator supplied with running seawater to maintain in situ temperature $\left( \pm 1^{\circ} \mathrm{C}\right)$ and incubated for $24 \mathrm{~h}$, with an exposure period to surface solar radiation from 10:00 to 18:00 h. SML sample collection started at 06:00 $\mathrm{h}$ and lasted for $\sim 1.5 \mathrm{~h}$. All measurements were performed in quadruplicate. Net primary production and community respiration were calculated as the difference in dissolved oxygen concentration between initial and final dissolved oxygen concentrations in the light and dark incubations, respectively.

The concentration of dissolved oxygen was determined by Winkler titration of whole bottles. Titration was done with an automated potentiometric end-point detection system (Metrohm DMS 716), following the recommendations of Carignan et al. (1998). Respiration rates, net community production rates and rates of photochemical oxygen consumption (see later subsection) $\leq 0.2 \mu \mathrm{mol} \mathrm{O} \mathrm{O}^{-1} \mathrm{~d}^{-1}$ were not significantly different from zero (Student's $t$-test, $\mathrm{p}>0.05$ ).

Bacterial respiration and bacterial growth efficiency (BGE). In a subset of samples at Stn SOLA (June 12 , and July 1, 5, 7, and 9), the contribution of heterotrophic bacteria to community respiration and bacterial growth efficiency were determined in $0.8 \mu \mathrm{m}$ filtered samples (polycarbonate filters, Millipore $90 \mathrm{~mm}$ filter diameter). For bacterial respiration, part of the $<0.8 \mu \mathrm{m}$ filtrate was incubated in BOD bottles for $24 \mathrm{~h}$ in the dark as described in last subsection above. Bacterial production (BP, see later subsection below) was measured in the $<0.8 \mu \mathrm{m}$ filtrate prior and following a $24 \mathrm{~h}$ incubation in the dark at in situ temperature. BGE was subsequently determined from bacterial respiration and the mean value of bacterial production determined prior and after the $24 \mathrm{~h}$ incubation of the $<0.8 \mu \mathrm{m}$ filtrate.

Photochemical oxygen demand. Photochemical oxygen consumption was measured in $0.2 \mu \mathrm{m}$ filtered (polycarbonate filters, Millipore $90 \mathrm{~mm}$ filter diameter) water samples. Samples were incubated in quartzglass BOD bottles as described earlier from 10:00 to 18:00 h.

Enumeration of heterotrophic bacteria, autotrophic prokaryotic and eukaryotic cells by flow cytometry analysis. Subsamples (3 ml) were fixed with $2 \%$ formaldehyde; these were incubated for $30 \mathrm{~min}$ at $4^{\circ} \mathrm{C}$, then frozen in liquid nitrogen and stored at $-80^{\circ} \mathrm{C}$ until analysis. Samples were analyzed within 6 mo. For flow cytometry analysis of heterotrophic bacteria, samples 
were stained with the nucleic acid dye SYBR Green-I (Molecular Probes) at $0.025 \%$ (vol/vol) final concentration (Lebaron et al. 1998). Counts were performed on a FACS-Calibur flow cytometer (Becton Dickinson) equipped with a $488 \mathrm{~nm}$ wavelength, $15 \mathrm{~mW}$ Argon laser. Stained bacteria were excited at $488 \mathrm{~nm}$ wavelength and discriminated according to their right angle-light scatter (SSC, related to cell size) and green fluorescence at $530 \pm 15 \mathrm{~nm}$ wavelength. Enumeration of autotrophic cells was performed according to Marie et al. (2000). Synechococcus spp. were discriminated by their strong orange fluorescence $(>630 \mathrm{~nm})$ and pico- and nanoeukaryotes were discriminated by their scatter signals of the red fluorescence at $585 \pm 21 \mathrm{~nm}$.

Enumeration of particle-attached bacteria and hetero- and autotrophic protists. The contribution of particle-attached bacteria to total bacterial abundance and the abundance of heterotrophic and autotrophic flagellates were determined for samples from Stns SOLA and MOLA. Raw seawater samples $(20 \mathrm{ml})$ were fixed with $2 \%$ formaldehyde (final conc.) and stored at $4^{\circ} \mathrm{C}$ for up to $1 \mathrm{mo}$. Samples were stained with DAPI (Porter \& Feig 1980) and filtered onto $0.2 \mu \mathrm{m}$ Nuclepore PC filters. Enumeration was performed with an epifluorescence microscope (Olympus AX 70) at 1250× magnification. The abundance of particle-attached bacteria and heterotrophic protists was determined using an excitation filter of $365 \mathrm{~nm}$, while an excitation wavelength of $480 \mathrm{~nm}$ was used for the identification of autofluorescent cells (Sherr et al. 1993). Attached bacterial cells were directly counted on particles and distinguished from free-living cells on the same slide.

Bacterial production. Bacterial production was measured in the $<0.8 \mu \mathrm{m}$ size fraction by $\left[{ }^{3} \mathrm{H}\right]$ leucine (specific activity $160 \mathrm{Ci} \mathrm{mmol}^{-1}$; final conc. $10 \mathrm{nM}$ ) incorporation (Simon \& Azam 1989). Incubation of triplicate $5 \mathrm{ml}$ subsamples and 2 blanks was performed in the dark for $1 \mathrm{~h}$. Blanks were fixed with formaldehyde (final conc. $4 \%$, v/v) 10 min before adding the tracer. Following incubation, the samples were fixed with formaldehyde (final conc. $4 \%, \mathrm{v} / \mathrm{v}$ ) and subsequently filtered onto $0.2 \mu \mathrm{m}$ cellulose nitrate filters (Millipore HA, $25 \mathrm{~mm}$ diameter filter). The filters were rinsed twice with $10 \mathrm{ml}$ ice-cold $5 \%$ trichloracetic acid (Sigma Chemicals). The filters were subsequently dissolved in $1 \mathrm{ml}$ ethyl acetate and, after $10 \mathrm{~min}, 8 \mathrm{ml}$ of scintillation cocktail (PCS Amersham) were added. The radioactivity incorporated into bacterial cells was counted in a Canberra Packard Tricarb 2000 and the disintegrations per minute converted to the actual amount of substrate taken up. A factor of $1.55 \mathrm{~kg} \mathrm{C} \mathrm{mol}^{-1}$ leucine was used to convert the incorporation of leucine to carbon equivalents (Simon \& Azam 1989).

Concentration of dissolved (DOC) and particulate organic carbon (POC). For DOC analysis, samples were filtered through combusted $\left(450^{\circ} \mathrm{C}\right.$ for $\left.5 \mathrm{~h}\right)$ Whatman GF/F filters and preserved by adding $\mathrm{HgCl}_{2}\left(5 \mathrm{mg} \mathrm{l}^{-1}\right)$. Subsamples $(20 \mathrm{ml})$ were stored in combusted glass vials with Teflon-lined screw caps in the dark at ambient temperature for $\sim 6$ mo until analyzed. DOC measurements were performed on a Shimadzu TOC-5000 (Benner \& Strom 1993). Prior to injection, DOC samples were acidified with $10 \mathrm{~N} \mathrm{H}_{3} \mathrm{PO}_{4}$ to $\mathrm{pH} 2$ and sparged with $\mathrm{CO}_{2}$-free air for $10 \mathrm{~min}$ to remove inorganic carbon. One hundred $\mu \mathrm{l}$ of sample were injected in triplicate, and analytical precision was $\sim 2 \%$. Standards were prepared with potassium hydrogen biphtalate. For POC analysis, $1000 \mathrm{ml}$ samples were filtered onto combusted Whatman GF/F filters. Subsequently, the filters were rinsed with $\sim 10 \mathrm{ml}$ of Milli-Q water to remove salts. The filters were stored frozen $\left(-20^{\circ} \mathrm{C}\right)$ until analysis. POC measurements were performed by dry combustion of the filters on the solid sampling module (SSM) of the TOC 5000 with a combustion tube at $900^{\circ} \mathrm{C}$ (Tan \& Strain 1979). Prior to combustion, the filters were acidified with $5 \mathrm{~N} \mathrm{H}_{3} \mathrm{PO}_{4}$ in silica boats and dried at $50^{\circ} \mathrm{C}$ for $\sim 2 \mathrm{~h}$ to remove carbonates and most of the remaining acid and water. Following high temperature oxidation, the $\mathrm{CO}_{2}$ was measured with a non-dispersive infrared detector (NDIR) with a standard deviation of $\sim 2 \%$.

Statistical analysis. The Wilcoxon test for matched pairs was used to test differences of variables between samples collected in the SML and the SSW. Statistics were performed with Stat View 5.0.

In the present study, enrichment factors (EF) were determined as the ratio between the concentration or activity in the samples collected by the metal screen (SML) and the SSW.

\section{RESULTS}

\section{Chemical and biological characterization of the SML}

Concentrations of dissolved (DOC) and particulate organic carbon (POC) in the SSW were highest in the River Rhône (132 and $198 \mu \mathrm{M}$ for DOC and POC, respectively) and decreased to the offshore Stn MOLA (86 and $4 \mu \mathrm{M}$ for DOC and POC, respectively; Table 3). At all stations, the SML was enriched in DOC $(p=0.003$, $\mathrm{n}=11$, Wilcoxon test, data from all sites pooled) with a mean EF of 1.3. Substantially higher EF were detectable for POC (mean EF 7.8) ( $p=0.018, n=7$, Wilcoxon test, data from all sites pooled; Table 3 ). The EF of DOC were independent of the DOC concentrations in the SSW. In contrast, the highest EF for POC were detected at Stns SOLA and MOLA, characterized by comparatively low SSW concentrations of POC. The relative contribution of POC to total organic carbon (TOC) was 1.2- to 6.7-fold higher in the SML than the SSW (Table 3). 
Table 3. Concentration (mean $\pm \mathrm{SD}$ ) of dissolved (DOC) and particulate organic carbon (POC) in the subsurface water (SSW) with respective enrichment factors (EF: ratio SML:SSW samples) for the surface microlayer (SML), and relative contribution of POC to total organic carbon (TOC)

\begin{tabular}{|c|c|c|c|c|c|c|}
\hline \multirow[t]{2}{*}{ Stn } & \multicolumn{2}{|c|}{$\mathrm{DOC}(\mu \mathrm{M})$} & \multicolumn{2}{|c|}{ POC $(\mu \mathrm{M})$} & \multicolumn{2}{|c|}{ POC:TOC (\%) } \\
\hline & SSW & EF & SSW & $\mathrm{EF}$ & SSW & SML \\
\hline River Rhône & $\begin{array}{c}132 \\
(\mathrm{n}=1)\end{array}$ & 1.2 & $\begin{array}{c}198 \\
(\mathrm{n}=1)\end{array}$ & 1.9 & $\begin{array}{c}60 \\
(n=1)\end{array}$ & 71 \\
\hline Rhône Estuary & $\begin{array}{l}94 \pm 3 \\
(\mathrm{n}=2)\end{array}$ & $1.7 \pm 0.1$ & $\begin{array}{l}23 \pm 5 \\
(\mathrm{n}=2)\end{array}$ & $5.0 \pm 1$ & $\begin{array}{c}20 \pm 1.9 \\
(\mathrm{n}=2)\end{array}$ & $42 \pm 2$ \\
\hline SOLA & $\begin{array}{r}89 \pm 10 \\
(\mathrm{n}=6)\end{array}$ & $1.3 \pm 0.2$ & $\begin{array}{c}5 \pm 1 \\
(n=2)\end{array}$ & $14.0 \pm 6$ & $\begin{array}{l}6 \pm 0.1 \\
(\mathrm{n}=2)\end{array}$ & $40 \pm 9$ \\
\hline MOLA & $\begin{array}{l}86 \pm 6 \\
(n=2)\end{array}$ & $1.2 \pm 0.1$ & $\begin{array}{c}4 \pm 1 \\
(\mathrm{n}=2)\end{array}$ & $7.3 \pm 2$ & $\begin{array}{l}5 \pm 0.8 \\
(\mathrm{n}=2)\end{array}$ & $23 \pm 6$ \\
\hline
\end{tabular}

\section{Community and bacterial respiration and net community production}

Community respiration in the SSW varied considerably among study sites, ranging from $39.2 \mu \mathrm{mol} \mathrm{O} \mathrm{O}^{-1} \mathrm{~d}^{-1}$ in the River Rhône to as low as $0.2 \mu \mathrm{mol} \mathrm{O} \mathrm{I}^{-1} \mathrm{~d}^{-1}$ at Stn SOLA (Fig. 1). At all study sites, community respiration in the SML exceeded that in the SSW by factors varying between 1.7 and $28(\mathrm{p}=0.0007, \mathrm{n}=15$, Wilcoxon test; data from all sites pooled). Across systems, community respiration in the SML was related to the concentration of TOC (Fig. 2). No relationship was detectable be-
The abundance of the most dominant members of the hetero- and autotrophic community was highest in SSW of the River Rhône (except for Synechococcus spp.) and decreased toward Stn MOLA (Table 4). The SML was significantly enriched in heterotrophic prokaryotes, heterotrophic protists, Synechococcus spp., pico- and nanoeukaryotes by factors varying between 1.1 and 5.6 ( $\mathrm{p}<0.05$ for each parameter analyzed, Wilcoxon test, data from all sites pooled). Similar EF of auto- and heterotrophic organisms were determined for the different stations, even though abundances of hetero- and autotrophic organisms in the SSW varied considerably among stations. At Stns SOLA and MOLA, the abundance of particle-attached bacteria was $\sim 10$-fold higher in the SML (mean $16.8 \times 10^{5}$ cells $\mathrm{l}^{-1}, \mathrm{n}=10$ ) than in the SSW (mean $1.5 \times 10^{5}$ cells $\mathrm{l}^{-1}, \mathrm{n}=10$ ). However, particle-attached bacteria accounted for only 3 and $0.3 \%$ of total bacterial abundance in the SML and the SSW, respectively.

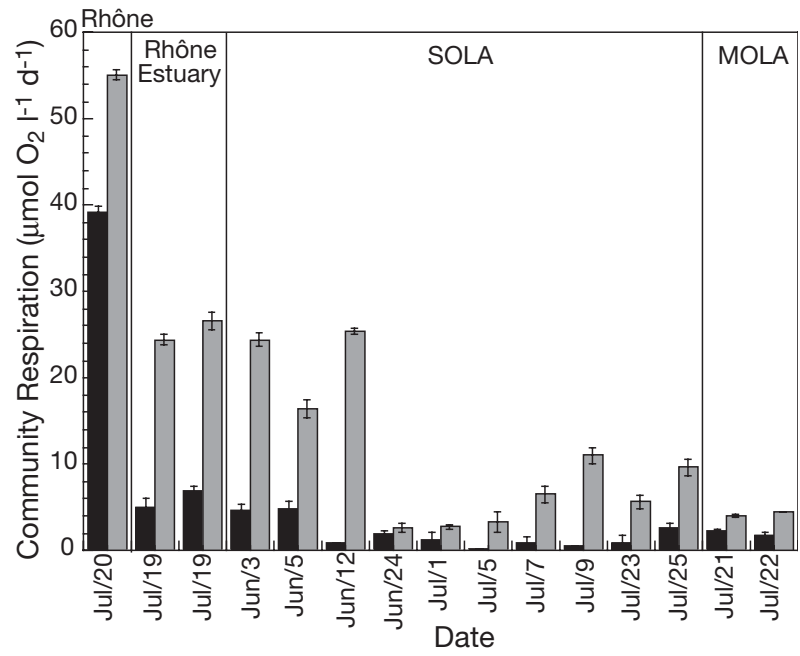

Fig. 1. Community respiration (mean $\pm \mathrm{SD}$ ) in subsurface waters (black bars) and in the surface microlayer (gray bars) at freshwater, estuarine and marine sites. SOLA: Station d'Observation Laboratoire Arago; MOLA: Microbial Observatory Laboratoire Arago

Table 4. Abundance (mean $\pm \mathrm{SD}$ ) of different members of the heterotrophic and autotrophic community in subsurface waters (SSW) with respective enrichment factors (EF) for the surface microlayer (SML). nd: not determined

\begin{tabular}{|c|c|c|c|c|c|c|c|c|c|c|}
\hline \multirow{3}{*}{ Stn } & \multicolumn{4}{|c|}{ Heterotrophic -} & \multirow{2}{*}{\multicolumn{2}{|c|}{$\begin{array}{c}\text { Synechococcus spp. } \\
\left(\times 10^{7} 1^{-1}\right)\end{array}$}} & \multirow{2}{*}{\multicolumn{2}{|c|}{$\begin{array}{c}\text { Autotrophic } \\
\text { Picoeukaryotes } \\
\left(\times 10^{6} \mathrm{l}^{-1}\right)\end{array}$}} & \multirow{2}{*}{\multicolumn{2}{|c|}{$\begin{array}{c}\text { Nanoeukaryotes } \\
\left(\times 10^{6} \mathrm{l}^{-1}\right)\end{array}$}} \\
\hline & \multicolumn{2}{|c|}{$\begin{array}{c}\text { Prokaryotes } \\
\left(\times 10^{9} \mathrm{l}^{-1}\right)\end{array}$} & \multicolumn{2}{|c|}{$\begin{array}{l}\text { Protists } \\
\qquad\left(\times 10^{6} \mathrm{l}^{-1}\right)\end{array}$} & & & & & & \\
\hline & SSW & EF & SSW & $\mathrm{EF}$ & SSW & EF & SSW & $\mathrm{EF}$ & SSW & $\mathrm{EF}$ \\
\hline River Rhône & $\begin{array}{c}8.0 \\
(\mathrm{n}=1)\end{array}$ & 1.0 & nd & nd & $\begin{array}{c}0.5 \\
(\mathrm{n}=1)\end{array}$ & 0.8 & 28.3 & 1.0 & $\begin{array}{l}30.5 \\
(\mathrm{n}=1)\end{array}$ & 0.9 \\
\hline Rhône Estuary & $\begin{array}{c}1.4 \pm 0.4 \\
(\mathrm{n}=2)\end{array}$ & $1.2 \pm 0.1$ & nd & nd & $\begin{array}{c}3.7 \pm 0.6 \\
(\mathrm{n}=2)\end{array}$ & $1.2 \pm 0.2$ & $\begin{array}{c}3.1 \pm 0.9 \\
(\mathrm{n}=2)\end{array}$ & $1.5 \pm 0.1$ & $\begin{array}{c}2.2 \pm 0.9 \\
(\mathrm{n}=2)\end{array}$ & $2.7 \pm 0.2$ \\
\hline SOLA & $\begin{array}{l}0.75 \pm 0.2 \\
\quad(\mathrm{n}=9)\end{array}$ & $1.2 \pm 0.1$ & $\begin{array}{c}0.9 \pm 0.6 \\
(\mathrm{n}=9)\end{array}$ & $2.7 \pm 1.9$ & $\begin{array}{c}3.5 \pm 1.7 \\
(\mathrm{n}=9)\end{array}$ & $1.1 \pm 0.2$ & $\begin{array}{c}1.7 \pm 0.5 \\
(\mathrm{n}=9)\end{array}$ & $1.2 \pm 0.2$ & $\begin{array}{c}0.6 \pm 0.3 \\
(\mathrm{n}=9)\end{array}$ & $1.7 \pm 0.5$ \\
\hline MOLA & $\begin{array}{l}0.53 \pm 0.0 \\
(\mathrm{n}=2)\end{array}$ & $1.3 \pm 0.1$ & $\begin{array}{c}0.3 \\
(\mathrm{n}=1)\end{array}$ & 5.6 & $\begin{array}{c}1.9 \pm 0.2 \\
(\mathrm{n}=2)\end{array}$ & $1.1 \pm 0.0$ & $\begin{array}{c}0.7 \pm 0.4 \\
(\mathrm{n}=2)\end{array}$ & $1.8 \pm 0.8$ & $\begin{array}{c}0.5 \pm 0.2 \\
(\mathrm{n}=2)\end{array}$ & $1.4 \pm 0.6$ \\
\hline
\end{tabular}




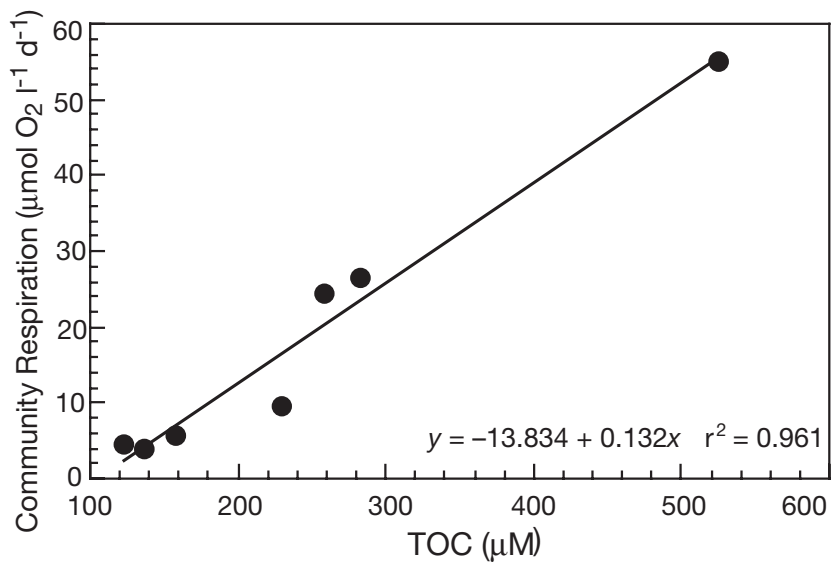

Fig. 2. Community respiration and concentration of total organic carbon (TOC) in the surface microlayer of samples collected in the River Rhône, its estuary, and at Stns SOLA and MOLA

tween community respiration and the abundance of the major groups of the hetero- and autotrophic community.

At Stn SOLA, bacterial respiration $(<0.8 \mu \mathrm{m}$ size fraction) accounted for $100 \%$ of the community respiration in the SSW (Table 5). In the SML, however, the relative contribution of bacterial respiration to community respiration was substantially lower, ranging from 27 to $75 \%$ (Table 5). Initial bacterial production in the $<0.8 \mu \mathrm{m}$ size fraction was similar for the SML (mean $\left.0.09 \pm 0.05 \mu \mathrm{C}^{-1} \mathrm{~h}^{-1}, \mathrm{n}=4\right)$ and the $\operatorname{SSW}(0.10 \pm$ $\left.0.03 \mu \mathrm{g} \mathrm{Cl}^{-1} \mathrm{~h}^{-1}, \mathrm{n}=4\right)$. After incubation in the dark for $24 \mathrm{~h}$, bacterial production was 4.2 -fold higher in the

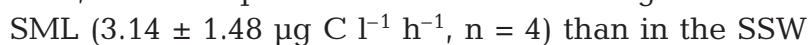
$\left(0.74 \pm 0.18 \mu \mathrm{g} \mathrm{C} \mathrm{l}^{-1} \mathrm{~h}^{-1}, \mathrm{n}=4\right)$. Bacterial growth efficiency varied between 42 to $44 \%$ and 18 to $83 \%$ in the SSW and the SML, respectively (Table 5).

Measurements of net community metabolism, determined in a subset of samples at Stns SOLA and MOLA, revealed negative values for the SML, varying between -11.1 and $-1.0 \mu \mathrm{mol} \mathrm{O} \mathrm{O}^{-1} \mathrm{~d}^{-1}$ (Fig. 3a). In

Table 5. Bacterial respiration $(<0.8 \mu \mathrm{m}$ size fraction), bacterial growth efficiency (BGE) and the relative contribution of bacterial respiration (BR) to community respiration $(\mathrm{CR})$ in the subsurface water (SSW) and the surface microlayer $(\mathrm{SML})$ at Stn SOLA. Data are means $\pm \mathrm{SD}, \mathrm{n}=4$. nd: not determined

\begin{tabular}{|lcccccc|}
\hline $\begin{array}{l}\text { Date } \\
(2003)\end{array}$ & \multicolumn{2}{c}{$\begin{array}{c}\text { Bacterial respiration } \\
\left(\mu \mathrm{mol} \mathrm{O}_{2} \mathrm{l}^{-1} \mathrm{~d}^{-1}\right)\end{array}$} & \multicolumn{2}{c}{$\begin{array}{c}\text { BGE } \\
(\%)\end{array}$} & \multicolumn{2}{c|}{$\begin{array}{c}\text { BR contribution to CR } \\
(\%)\end{array}$} \\
& SSW & SML & SSW & SML & SSW & SML \\
\hline Jun 12 & nd & $8.7 \pm 0.3$ & nd & nd & nd & 34 \\
Jul 01 & $1.3 \pm 0.6$ & $0.9 \pm 0.3$ & 44 & 83 & 100 & 33 \\
Jul 05 & $0.2^{\mathrm{a}}$ & $0.9 \pm 0.3$ & nd & 81 & nd & 27 \\
Jul 07 & $0.8 \pm 0.3$ & $4.9 \pm 0.7$ & 42 & 18 & 100 & 75 \\
Jul 09 & $0.2^{\mathrm{a}}$ & $8.2 \pm 0.7$ & nd & 31 & nd & 75 \\
and significantly different from zero & & & & \\
\hline
\end{tabular}

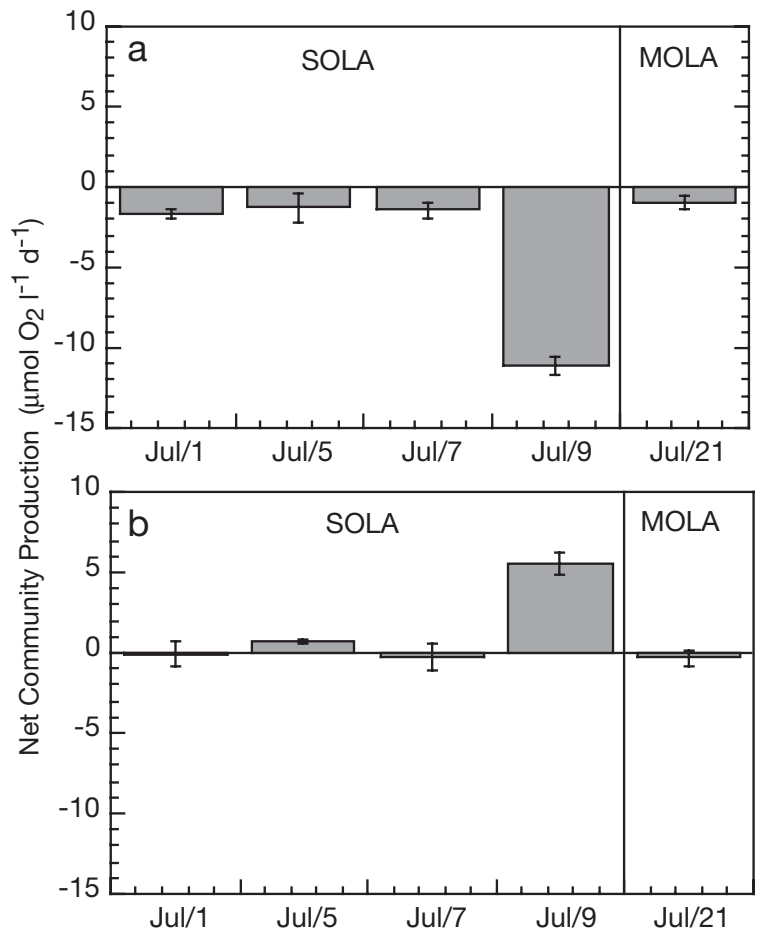

Fig. 3. Net community production (mean $\pm \mathrm{SD}$ ) of (a) the surface microlayer and (b) the subsurface water at Stns SOLA and MOLA

contrast, in the SSW, net community metabolism varied between -0.3 and $5.6 \mu \mathrm{mol} \mathrm{O} \mathrm{O}^{-1} \mathrm{~d}^{-1}$ (Fig. 3b). Gross primary production ranged between 0.1 and $5.1 \mu \mathrm{mol} \mathrm{O} \mathrm{l}^{-1} \mathrm{~d}^{-1}$ and 0.7 and $6.2 \mu \mathrm{mol} \mathrm{O} \mathrm{O}^{-1} \mathrm{~d}^{-1}$ in the SML and the SSW, respectively.

\section{Photochemical oxygen demand}

At Stn SOLA, the photochemical oxygen demand was determined in a subset of samples in July 2003. Photochemical oxygen consumption in $0.2 \mu \mathrm{m}$ filtered water collected from the SML and the SSW and exposed to one daylight period varied between 0.2 and $1.0 \mu \mathrm{mol} \mathrm{O} \mathrm{l}^{-1} \mathrm{~d}^{-1}$ (Table 6). No significant differences between the photochemical oxygen demand in the SML and the SSW were detectable.

\section{DISCUSSION}

Distinct differences in hetero- and autotrophic processes between the SML and bulk waters were observed in the present study. Measurements of metabolic activity in the SML are chal- 
Table 6. Photochemical oxygen demand (POD) of water collected from the subsurface water (SSW) and from the surface microlayer (SML) and DOC-normalized POD for samples incubated for $8 \mathrm{~h}$ to surface solar radiation. Data are means $\pm \mathrm{SD}$ are given; $\mathrm{n}=4$. nd: not determined

\begin{tabular}{|c|c|c|c|c|}
\hline \multirow[t]{2}{*}{$\begin{array}{l}\text { Date } \\
(2003)\end{array}$} & \multicolumn{2}{|c|}{$\begin{array}{c}\text { POD } \\
\left(\mu \mathrm{mol} \mathrm{O} \mathrm{l}^{-1} \mathrm{~d}^{-1}\right)\end{array}$} & \multicolumn{2}{|c|}{$\begin{array}{c}\text { DOC-normalized POD } \\
\left(\mathrm{nmol} \mathrm{O}_{2}[\mu \mathrm{M} \text { DOC }]^{-1} \mathrm{~d}^{-1}\right)\end{array}$} \\
\hline & SSW & SML & SSW & SML \\
\hline Jul 1 & $0.9 \pm 0.1$ & $1.0 \pm 0.4$ & $9.5 \pm 0.3$ & $8.7 \pm 0.3$ \\
\hline Jul 5 & $0.5 \pm 0.1$ & $0.2^{\mathrm{a}}$ & $5.4 \pm 0.2$ & nd \\
\hline Jul 7 & $0.2^{\mathrm{a}}$ & $0.5 \pm 0.2$ & nd & $5.3 \pm 0.2$ \\
\hline
\end{tabular}

lenging because the separation of SML water from its natural environment could result in important changes in physical properties specific for the air-water interface. In the context of the present study, 1 potentially important aspect is the intensity of solar irradiation. For net primary production, water collected from the uppermost $250 \mu \mathrm{m}$ layer was incubated in quartz BOD bottles, at a diameter of $5 \mathrm{~cm}$. Based on attenuation coefficients at Stn SOLA (F. Joux unpubl. data), we calculated that the intensities of PAR, UV-A and UV-B radiation decreased by $<1, \sim 2$ and $3 \%$, respectively, at $5 \mathrm{~cm}$ compared to surface radiation. This suggests that our incubation bottles reflected irradiation intensities at the sea surface fairly well. We recognize that the biological processes as determined in our incubation experiments probably do not fully represent in situ rates. However, we consider that our results represent important and significant information on the inherent properties of the SML compared to bulk waters.

\section{Enhanced mineralization in the sea surface microlayer}

The enhanced community respiration rates in the SML indicate the importance of organic matter mineralization at the air-water interface. Based on the abundance of the most dominant members of the hetero- and autotrophic community $<20 \mu \mathrm{m}$ and the carbon biomass of individual cells $\left(20 \mathrm{fg} \mathrm{C} \mathrm{cell}^{-1}\right.$ for heterotrophic bacteria [Lee \& Furhman 1987], $250 \mathrm{fg} \mathrm{C}$ cell $^{-1}$ for Synechococcus spp., $2100 \mathrm{fg} \mathrm{C} \mathrm{cell}^{-1}$ for picoeukaryotes and heterotrophic protists [Campbell et al. 1994]), we estimated a biomass contribution to the POC pool of $\sim 10$ and $40 \%$ in the SML and the SSW, respectively. A similar contribution $(<150 \mu \mathrm{m}$ size fraction, 17 and $37 \%$ for the SML and the SSW, respectively) was obtained by Mimura et al. (1988) for the Bay of Marseille, using ATP carbon as a proxy for total living biomass. Thus, more detrital material accumu- lates in the SML than in the SSW. This is also indicated by higher ratios of phaeophytin:chla and C:N in the SML compared to the SSW (Nishizawa 1971, Taguchi \& Nakajiama 1971, De Souza Lima \& ChretiennotDinet 1984, Agogué et al. 2004). The accumulation of detrital organic matter, mostly in colloidal and particulate form, is likely responsible for the enhanced respiration rates at the air-water interface.

Heterotrophic processes clearly dominated over autotrophic production in the SML, while in the SSW autotrophic processes balanced or exceeded heterotrophic processes. In a study performed in the oligotrophic open ocean $\left(\sim 0.06 \mu \mathrm{g} \mathrm{chl} \mathrm{a} \mathrm{l^{-1 }}\right.$ in SSW), the primary production (based on ${ }^{14} \mathrm{C}$ incorporation) of the phytoneuston was only $50 \%$ of the production of the phytoplankton at $1 \mathrm{~m}$ depth (Williams et al. 1986). This difference was attributed to photoinhibition of phytoneuston activity (Williams et al. 1986). The same conclusion was drawn from an experiment performed in the Fraser River Estuary (Albright 1980). In the present study, water samples from the SML and the SSW were both exposed to surface intensities of solar radiation. We calculated that the intensities of PAR, UV-A and UV-B radiation in the SSW (at $0.3 \mathrm{~m}$ depth) were $\sim 3,7$ and $14 \%$, respectively, lower than at the sea surface. Hetero- and autotrophic processes are both prone to photoinhibition, but the effect is more important for primary production because autotrophic activity is limited to the daylight period. Due to the rapid decrease with depth of harmful UV-B radiation, net community metabolism was likely underestimated for the SSW in the present study, indicating that the observed difference in net community metabolism between the SML and the SSW is even more pronounced at in situ irradiation intensities. This suggests that photoinhibition of phytoneuston activity is likely one important mechanism for the imbalance of hetero- and autotrophic processes in the SML in the oligotrophic marine environment.

\section{Photochemical processes in the surface microlayer}

Photochemical oxygen demand is an indicator of the photochemical mineralization of organic carbon (Lindell \& Rai 1994, Amon \& Benner 1996). In the present study, in 2 out of 3 experiments, the photochemical oxygen demand was higher in the SML as compared to the SSW (Table 6). When normalized to the concentration of DOC, photochemical oxygen demand for the SML was similar to that for the SSW, varying between 5 and $10 \mathrm{nmol} \mathrm{O}_{2}[\mu \mathrm{M} D O C]^{-1} \mathrm{~d}^{-1}$. These values are similar to those determined for water collected at $10 \mathrm{~m}$ depth in the coastal Northern Adriatic Sea (Obernosterer \& Herndl 2000), but are lower than those 
measured for surface water $(5 \mathrm{~m})$ in the subtropical Atlantic Ocean (12 to $29 \mathrm{nmol} \mathrm{O}_{2}[\mu \mathrm{M} \mathrm{DOC}]^{1} \mathrm{~d}^{-1}$, Obernosterer et al. 2001). This difference is likely attributable to the roughly 2 -fold higher intensity of UV-B radiation measured during the exposure period in the subtropical Atlantic Ocean compared to that measured in the present study in the Mediterranean Sea. The similar DOC-normalized photochemical oxygen consumption rates in the SML and the SSW indicate a similar photochemical reactivity of the DOM of these 2 layers. In the present study, DOM from the SML and the SSW were both exposed to the same irradiation intensities. The higher irradiation intensities at the air-water interface in the SML compared to the SSW, and the accumulation of organic matter in the SML, could however result in a significant impact of photochemical processes on the cycling of DOM at the air-water interface.

\section{Bacterial contribution to community respiration}

In 4 independent experiments conducted at Stn SOLA over a period of 10 d in July 2003, an increase in community respiration in the SML from July 1 to 9 was observed (Fig. 1). Interestingly, the highest community respiration rates in the SML on July 7 and 9 coincided with the highest relative contributions of bacterial respiration to community respiration and to the lowest BGE (Table 5). These results suggest that the increase in community respiration is attributable to an increase in bacterial respiration due to low BGE. The biological reactivity of DOM determines the BGE (del Giorgio \& Cole 2000). Changes in the biological reactivity of DOM on short temporal scales (hours to days) could

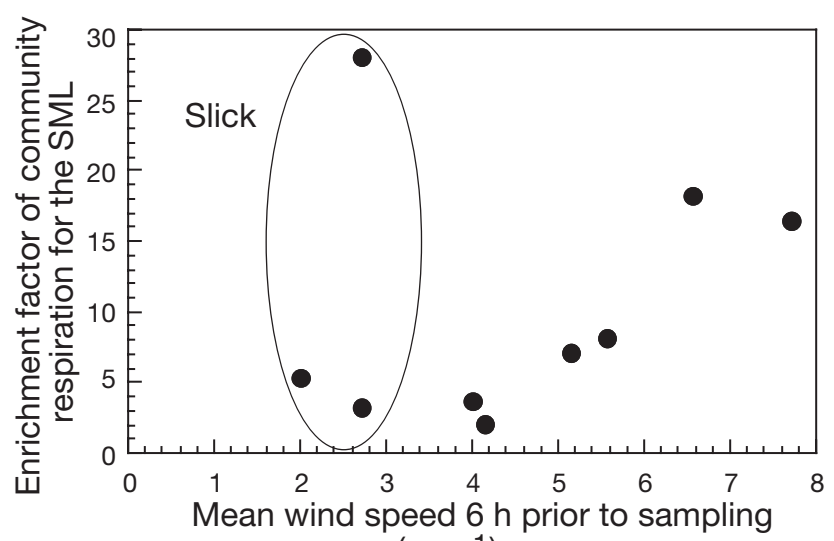

$\left(\mathrm{m} \mathrm{s}^{-1}\right)$

Fig. 4. Enrichment factors (EF: ratio SML:SSW samples) of community respiration in the surface microlayer (SML) at Stn SOLA and mean wind speed $6 \mathrm{~h}$ prior to sampling. Encircled data ('Slick'): EF of water collected in visible surface slicks result from photochemical transformations of the DOM. Bacterial consumption of photoproducts, in particular the more oxidized carbon compounds (see review by Mopper \& Kieber 2002), could lead to a decrease in the overall BGE.

\section{Surface microlayer enrichment from subsurface waters}

External sources of organic matter, in the oceanic environment mainly from the SSW, appear to be a major source of enrichment for the SML (Zutic et al. 1981, Kuznetsova et al. 2004). Turbulent mixing, the upward transport of bouyant particles, or bubble scavenging are important mechanisms (Liss et al. 1997). Eolian input of terrestrial material could, particularly in the coastal environment, contribute to the accumulation of organic matter at the air-sea interface. The relative contribution of these processes, however, is largely unknown.

In the present study, the EF of community respiration at Stn SOLA in July 2003 were positively correlated with the mean wind speed $6 \mathrm{~h}$ prior to sampling up to $\sim 7 \mathrm{~m} \mathrm{~s}^{-1}$ (Fig. 4). For comparison, in June 2003 welldeveloped slicks were sampled, revealing highly variable EF for community respiration at low, but similar wind speeds (Fig. 4). The increase in the EF of community respiration in the SML with increasing wind speed is in accordance with results from a previous study by Falkowska (1999), who observed an increase in the thickness of the SML in the coastal Baltic Sea with increasing wind speed (up $\sim 8 \mathrm{~m} \mathrm{~s}^{-1}$ ). Similarly, SML enrichments in DOC (Carlson 1983) and dissolved and particulate amino acids (Kuznetsova et al. 2004) were detectable up to $\sim 8 \mathrm{~m} \mathrm{~s}^{-1}$. The SML is in continuous exchange with the SSW. Wind-generated mixing could be considered as a renewal mechanism, thereby increasing the vertical transport of potential SML material to the surface (Jarvis 1967, Liss et al. 1997). It was recently suggested, that in convergence areas the upward transport of buoyant particulate organic matter to the ocean surface represents an important mechanism as well (Dandonneau et al. 2003). The biogeochemical implications of such largescale input of organic matter at the air-water interface for the biogeochemical processes of this boundary layer warrants further investigation.

\section{Implications for the food web structure}

At first glance, the consistently high EF in community respiration rates at Stn SOLA conflict with those of a recent study where no significant enrichment in 
bacterial production in the SML as compared to SSW was detectable (Agogué et al. 2004). One possible explanation is the lower BGE in the SML than in the SSW (Table 5). This assumption is based on the lower biological reactivity of SML organic matter, probably due to its higher degradation state. Differences in the food-web structure in the SML and the SSW could also account for the observed differences in bacterial production and community respiration. As shown in the present and previous studies (see review by Lian \& Leckie 1981), the SML is enriched in POC. Concurrently, heterotrophic protists had the highest EF of all members of the neuston community determined in the present and a previous study (Agogué et al. 2004). We hypothesize that POC could be the basis of the food web in the SML, thereby supporting heterotrophic organisms in the size class $>1 \mu \mathrm{m}$. The enrichment in heterotrophic protists and ciliates due to the high concentrations of POC could account for the high net heterotrophy of the SML.

In summary, we have shown that the SML is characterized by high rates of biological carbon mineralization. Based on the sampling device used in the present study, the SML is considered to comprise the upper $250 \mu \mathrm{m}$. The enrichment in organic matter could extend down to several centimeters depth, as shown recently for total dissolved carbohydrate concentrations (Momzikoff et al. 2004). High resolution vertical profiles in the upper $1 \mathrm{~m}$ depth layer would help identify the concentration gradient of organic and inorganic matter at the air-water interface. The expected increase in the concentration of dissolved inorganic carbon in the SML resulting from enhanced heterotrophic activity and photoremineralization possibly has important implications for gas exchange through the air-sea interface. The quantitative importance of this process remains to be determined.

Acknowledgements. We would like to thank the captain and the crew of the RV 'Tethys II' for their excellent cooperation and assistance with the surface microlayer sampling. We also thank G. Cauwet for help with the analysis of DOC and POC and J.-J. Naudin for obtaining wind speed data from Meteo France. The manuscript greatly benefited from suggestions of 3 anonymous reviewers. Financial support was provided by the European Commission through the projects AIRWIN (EVK3-CT2000-00030), BASICS (EVK3-CT2002-00078) and a Marie-Curie Individual Fellowship (MCFI 2002-00625) to I.O.

\section{LITERATURE CITED}

Agogué $\mathrm{H}$, Casamayor EO, Joux F, Obernosterer I and 7 others (2004) Comparison of samplers for the biological characterization of the sea surface microlayer. Limnol Oceanogr Methods 2:213-225

Albright L (1980) Photosynthetic activities of phytoneuston and phytoplankton. Can J Microbiol 26:389-392
Amon RMW, Benner R (1996) Photochemical and microbial consumption of dissolved organic carbon and dissolved oxygen in the Amazon River system. Geochim Cosmochim Acta 60:1783-1792

Bailey CA, Neihof RA, Tabor PS (1983) Inhibitory effect of solar radiation on amino acid uptake in Chesapeake Bay bacteria. Appl Environ Microbiol 46:44-49

Bell CR, Albright LJ (1982) Bacteriological investigation of the neuston and plankton in the Fraser River estuary, British Columbia. Estuar Coast Shelf Sci 15:385-394

Benner R, Strom M (1993) A critical evaluation of the analytical blank associated with DOC measurements by hightemperature catalytic oxidation. Mar Chem 41:153-160

Campbell L, Nolla HA, Vaulot D (1994) The importance of Prochlorococccus to community structure in the central north Pacific. Limnol Oceanogr 39:954-961

Carignan R, Blais AM, Vis C (1998) Measurement of primary production and community respiration in oligotrophic lakes using the Winkler method. Can J Fish Aquat Sci 55:1078-1084

Carlson DJ (1983) Dissolved organic materials in surface microlayers: temporal and spatial variability and relation to sea state. Limnol Oceanogr 28:415-431

Carlucci AF, Craven DB, Robertson KJ, Williams PM (1986) Surface film microbial populations: diel amino acid metabolism, carbon utilization, and growth rates. Mar Biol 92: 289-297

Dandonneau Y, Vega A, Loisel H, du Penhoat Y, Menkes C (2003) Oceanic rossby waves acting as a 'hay rake' for ecosystem floating by-products. Science 302:1548-1551

del Giorgio PA, Cole JJ (2000) Bacterial energetics and growth efficiency. In: Kirchman DL (ed) Microbial ecology of the oceans. Wiley-Liss, New York, p 289-325

De Souza Lima Y, Chretiennot-Dinet MJ (1984) Measurements of biomass and activity of neustonic microorganisms. Estuar Coast Shelf Sci 19:167-180

Dietz AS, Albright LJ, Tuominen T (1976) Heterotrophic activities of bacterioneuston and bacterioplankton. Can J Microbiol 22:1699-1709

Falkowska L (1999) Sea surface microlayer: a field evaluation of the Teflon plate, glass plate and screen sampling techniques. Part 1. Thickness of microlayer samples and relation to wind speed. Oceanologia 41:211-221

Garabétian F (1990) Production de $\mathrm{CO}_{2}$ à l'interface air-mer. Une approche par l'étude des phénomènes respiratoires dans la microcuche de surface. Int Rev Ges Hydrobiol 76: $219-229$

Garrett WD (1965) Collection of slick-forming materials from the sea-surface. Limnol Oceanogr 10:602-605

Häder DP, Lebert M, Marangoni R, Colombetti G (1999) ELDONET - European Light Dosimeter Network hardware and software. J Photochem Photobiol B 52:51-58

Hardy JT (1997) Biological effects of chemicals in the seasurface microlayer. In: Liss PS, Duce RA (eds) The sea surface and global change. Cambridge University Press, Cambridge, p 339-370

Hardy JT, Apts CW (1984) The sea-surface microlayer: phytoneuston productivity and effects of atmospheric particulate matter. Mar Biol 82:293-300

Hardy JT, Apts CW (1989) Photosynthetic carbon reduction: high rates in the sea-surface microlayer. Mar Biol 101: 411-417

Harvey RN, Young LY (1980) Enrichment and association of bacteria and particulates in salt marsh surface waters. Appl Environ Microbiol 39:894-899

Hermannson M, Dahlback B (1983) Bacterial activity at the air/water interface. Microb Ecol 9:317-328 
Hunter KA (1997) Chemistry of the sea-surface microlayer. In: Liss PS, Duce RA (eds) The sea surface and global change. Cambridge University Press, Cambridge, p 287-319

Jarvis NL (1967) Absorption of surface-active material at the sea-air interface. Limnol Oceanogr 12:213-221

Kuznetsova M, Lee C (2001) Enhanced extracellular enzymatic peptide hydrolysis in the sea-surface microlayer. Mar Chem 73:319-332

Kuznetsova M, Lee C, Aller J, Frew N (2004) Enrichment of amino acids in the sea surface microlayer at coastal and open ocean sites in the North Atlantic Ocean. Limnol Oceanogr 49:1605-1619

Lebaron P, Parthuisot N, Catala P (1998) Comparison of blue nucleic acid dyes for flow cytometric enumeration of bacteria in aquatic systems. Appl Environ Microbiol 64: 1725-1730

Lee S, Fuhrman JA (1987) Relationships between biovolume and biomass of naturally derived marine bacterioplankton. Appl Environ Microbiol 53:1298-1303

Lindell MJ, Rai H (1994) Photochemical oxygen consumption in humic waters. Ergeb Limnol 43:145-155

Lion LW, Leckie JO (1981) The biogeochemistry of the air-sea interface. Annu Rev Earth Planet Sci 9:449-486

Liss PS, Watson AJ, Bock EJ, Jähne B and 8 others (1997) Physical processes in the microlayer and the air-sea exchange of trace gases. In: Liss PS, Duce RA (eds) The sea surface and global change. Cambridge University Press, Cambridge, $\mathrm{p}$ 1-33

Marie D, Simon N, Guillou L, Partensky F, Vaulot D (2000) Flow cytometry analysis of marine picoplankton In: De Maggio (ed) Living color: protocols in flow cytometry and cell sorting. Springer Verlag, Berlin, p 421-454

Mimura T, Romano JC, Souza-Lima Y (1988) Microbiomass structure and respiratory activity of microneuston and microplankton in the northwestern Mediterranean Sea influenced by Rhône river water. Mar Ecol Prog Ser 49: 151-162

Momzikoff A, Brinis A, Dallot S, Gondry G, Saliot A, Lebaron $P$ (2004) Field study of the chemical characterization of the top ocean surface using various samplers. Limnol Oceanogr Methods 2:374-386

Mopper K, Kieber RJ (2002) Photochemistry and the cycling of carbon, sulfur, nitrogen and phosphorus. In: Hansell

Editorial responsibility: Jim W. Ammerman,

New Brunswick, New Jersey, USA
DA, Carlson CA (eds) Biogeochemistry of marine dissolved organic matter. Academic Press, San Diego, CA, p 455-507

Nishizawa S (1971) Concentration of organic and inorganic material in the surface skin at the equator, $155^{\circ} \mathrm{W}$. Bull Plankton Soc Jpn 18:42-44

Obernosterer I, Herndl GJ (2000) Differences in the optical and biological reactivity of the humic and non-humic DOC component in two contrasting coastal marine environments. Limnol Oceanogr 45:1120-1129

Obernosterer I, Ruardij P, Herndl GJ (2001) Spatial and diurnal dynamics of dissolved organic matter (DOM) fluorescence and $\mathrm{H}_{2} \mathrm{O}_{2}$ and the photochemical oxygen demand of surface water DOM across the subtropical Atlantic Ocean. Limnol Oceanogr 46:632-643

Porter KG, Feig Y (1980) The use of DAPI for identifying and counting aquatic microflora. Limnol Oceanogr 25:943-946

Sherr EB, Caron DA, Sherr BF (1993) Staining of heterotrophic protists for visualization via epifluorescence microscopy. In: Kemp PF, Sherr BF, Sherr EB, Cole JJ (eds) Handbook of methods for aquatic microbial ecology. Lewis Publishers, Boca Raton, FL, p 213-227

Sieburth JMcN, Willis PJ, Johnson KM, Burney CM and 6 others (1976) Dissolved organic matter and heterotrophic microneuston in the surface microlayers of the North Atlantic. Science 194:1415-1518

Simon M, Azam F (1989) Protein content and protein synthesis rates of planktonic marine bacteria. Mar Ecol Prog Ser 51:201-213

Taguchi S, Nakajima K (1971) Plankton and seston in the sea surface of three inlets of Japan. Bull Plankton Soc Jpn 18: $20-36$

Tan FC, Strain PM (1979) Carbon isotope ratios of particulate organic matter in the Gulf of St. Lawrence. J Fish Res Board Can 36:678-682

Williams PM, Carlucci AF, Henrichs SM, Van Vleet ES, Horrigan SG, Reid FMH, Robertson KJ (1986) Chemical and microbiological studies of sea surface films in the southern Gulf of California and off the west coast of Baja California. Mar Chem 19:17-98

Zutic VB, Cosovic B, Marcenko E, Biharu N (1981) Surfactant production by marine phytoplankton. Mar Chem 10: $505-520$

Submitted: April 9, 2004; Accepted: April 12, 2005

Proofs received from author(s): June 7, 2005 